\title{
LEMBAR KERJA SISWA BERBASIS MASALAH PADA MATERI BENTUK ALJABAR SISWA SMP
}

\author{
Paramita Dwi Pangastuti $^{1}$, Marhamah $^{2}$, Nora Surmilasari ${ }^{3}$ \\ Program Studi Pendidikan Matematika, Universitas PGRI Palembang ${ }^{1,2,3}$ \\ mithaparamithadwi@yahoo.com ${ }^{1}$, marhamah1904@gmail.com², \\ norasurmilasari@gmail.com ${ }^{3}$
}

\begin{abstract}
ABSTRAK
Penelitian ini bertujuan untuk menghasilkan Lembar Kerja Siswa SMP Berbasis Masalah yang valid dan praktis pada materi Bentuk Aljabar. Penelitian dan pengembangan ini menggunakan model pengembangan ADDIE (Analyze, Design, Development, Implementation, Evaluation), namun pada penelitian ini tahap implementation dibatasi hanya untuk ujicoba kelompok kecil (small group). Pengambilan data penelitian ini dilakukan di SMP Negeri 2 Sumber Marga Telang. Pelaksanaannya mulai dari permulaan sampai akhir penelitian yaitu dari September 2020 sampai Januari 2021. Hasil penelitian ini diperoleh dari aspek kevalidan dan kepraktisan: a) aspek kevalidan diperoleh berdasarkan tiga penilaian validator terhadap isi, konstruk, dan bahasa dengan skor validator pertama 90,76\% dalam kategori "sangat valid", skor validator kedua $82,25 \%$ dalam kategori "sangat valid", dan skor validator ketiga 84,55\% dalam kategori "sangat valid". b) aspek kepraktisan diperoleh berdasarkan 6 angket respon siswa yang diberikan pada tahap ujicoba kelompok kecil (small group) selesai dengan skor rata-rata 77,78\% dalam kategori "praktis".
\end{abstract}

Kata kunci : LKS, berbasis masalah, bentuk aljabar

\begin{abstract}
The purpose of this research is to create practical and legitimate Problem-Based Middle School Student Worksheets on Algebraic Forms material. The ADDIE development model (Analyze, Design, Development, Implementation, Evaluation) is used in this research and development, but the implementation phase is limited to small group trials in this study. This research's data was gathered at SMP Negeri 2 Sumber Marga Telang. The implementation period runs from the start of the research to the end of the research, from September 2020 to January 2021 . The validity and practicality aspects of this study were obtained: a) the validity aspect was obtained based on three validator assessments of content, construct, and language, with the first validator scoring 90.76 percent in the "very valid" category, the second validator scoring 82.25 percent in the "very valid" category, and the third validator scoring 84.55 percent in the "very valid" category. b) The practicality aspect is obtained based on six student response questionnaires administered during the small group trial stage, with an average score of 77.78 percent in the "practical" category.
\end{abstract}

Keywords : worksheets, problem based, algebraic form 


\section{PENDAHULUAN}

Pendidikan berfungsi penting dalam meningkatkan kualitas sumber daya manusia dalam kehidupan masyarakat yang cerdas, damai, terbuka serta demokrasi demi kemajuan bangsa. Pendidikan merupakan hal penting dalam kehidupan seharihari, oleh karena itu setiap manusia wajib menerima pendidikan. Belajar merupakan proses mengkonstruksi yang artinya berlangsung secara terus-menerus setiap kali berhadapan dengan fenomena atau persoalan yang baru. Menurut Ismail (2014) belajar diartikan sebagai perubahan tingkah laku berdasarkan perubahan dari diri dan adanya stimulus dari proses interaksinya dengan lingkungan.

Matematika merupakan salah satu mata pelajaran wajib yang diajarkan di setiap jenjang pendidikan. Terhitung dari sekolah dasar sampai ke jenjang pendidikan yang lebih tinggi (Kusumawati dan Irwanto, 2016). Pembelajaran matematika merupakan suatu proses belajar-mengajar yang dibentuk oleh guru untuk mengembangkan kemampuan berpikir siswa serta dapat meningkatkan kemampuan mengkonstruksikan pengetahuan sebagai upaya meningkatkan penguasaan yang baik terhadap materi matematika.

Pembelajaran matematika dinyatakan berhasil dengan baik jika hasil belajar siswa mencapai hasil yang optimal. Untuk mencapai hasil yang optimal maka diperlukan adanya dukungan dari semua pihak serta dukungan dari komponen pembelajaran. Salah satu komponen pembelajaran yaitu bahan ajar yang digunakan oleh guru. Bahan ajar merupakan segala bahan yang disusun secara sistematis yang menampilkan sosok utuh dari kompetensi yang akan dikuasai siswa dan digunakan dalam proses pembelajaran dengan tujuan untuk perencanaan dan penelaahan implementasi pembelajaran (Prastowo, 2014). Sejalan dengan Syaifullah dan Izzah (2019) bahan ajar adalah bahan atau materi pembelajaran yang disusun secara lengkap dan sistematis berdasarkan prinsip pembelajaran yang digunakan guru dan siswa dalam proses pembelajaran. Contoh dari bahan ajar berupa buku pelajaran, modul, lembar kerja siswa (LKS), handout, model atau maket, bahan ajar audio, dan bahan ajar interaktif (Prastowo, 2014).

Salah satu bahan ajar yang dapat digunakan guru untuk mengaktifkan proses pembelajaran adalah Lembar Kerja Siswa (LKS). Menurut Trianto (Tanjung dan Nababan, 2018) LKS merupakan panduan siswa yang digunakan dalam melakukan kegiatan penyelidikan atau pemecahan masalah. LKS merupakan bahan ajar cetak yang berupa lembaran kertas yang berisi materi, ringkasan, dan petunjuk pelaksanaan tugas pembelajaran yang harus dikerjakan siswa, baik bersifat teoritis atau praktis, yang memacu kepada kompetensi menggunakan lembar kerja siswa diharapkan pembelajaran lebih terarah serta membantu mengimplementasikan pengetahuan yang diperoleh dari kehidupan sehari-hari. Ada beberapa cara yang dapat dilakukan untuk mengembangkan lembar kerja siswa menjadi sedemikian rupa, salah satunya dengan menerapkan pembelajaran berbasis masalah (problem based learning) dalam menyajikan materi pada lembar kerja siswa. 
Pembelajaran berbasis masalah adalah metode pembelajaran yang menuntut adanya aktivitas siswa secara penuh dalam menyelesaikan setiap permasalahan yang dihadapi siswa secara mandiri dengan cara mengkonstruksikan pengetahuan dan pemahaman yang dimiliki (Wardoyo, 2013). Melalui lembar kerja siswa berbasis masalah, siswa diarahkan untuk mengembangkan kemampuan pengetahuan matematika yang baru serta siswa mampu memecahkan masalah dalam berbagai konteks yang berkaitan dengan matematika.

Salah satu materi yang harus dikuasai siswa saat belajar matematika di sekolah menengah pertama adalah materi aljabar. Aljabar merupakan salah satu cabang matematika yang sangat penting dalam membentuk karakter matematika pada siswa, karena dengan aljabar siswa dilatih untuk berpikir kritis, bernalar, kreatif dan berpikir abstrak. Dengan aljabar, siswa dikenalkan dengan variabel dan berbagai simbol matematika yang dapat digunakan untuk menyederhanakan kalimat menjadi model matematika dalam menyelesaikan masalah yang berkaitan dengan kehidupan sehari-hari. Menurut Hidayati (Yueni, 2018) dari hasil penelitiannya menunjukkan bahwa banyak siswa yang mengalami kesulitan saat awal belajar matematika. Sejalan dengan hal tersebut Hasibuan (2015) menyatakan bahwa siswa-siswi mengalami kesulitan dalam menyelesaikan soal-soal berbentuk ajlabar.

\section{METODE}

Penelitian ini merupakan jenis penelitian pengembangan. Model pengembangan yang digunakan adalah model pengembangan ADDIE (Analysis, Design, Development, Implementation, and Evaluation). Pengambilan data penelitian ini dilakukan di SMP Negeri 2 Sumber Marga Telang. Pelaksanaannya mulai dari permulaan sampai akhir penelitian yaitu dari September 2020 sampai Januari 2021.

Penelitian pengembangan bertujuan untuk mengembangkan dan menghasilkan suatu produk. Adapun produk yang dimaksud dalam penelitian ini ialah Lembar Kerja Siswa (LKS) berbasis masalah dalam pembelajaran matematika siswa kelas VII Sekolah Menengah Pertama (SMP). Model pengembangan yang digunakan dalam penelitian ini mengadaptasi dari model ADDIE yang dikembangkan oleh Dick and Carry (Mulyatiningsih, 2012) yaitu sebagai berikut:

\section{Tahap Analysis}

Pada tahap ini, kegiatan utama yaitu menganalisis kebutuhan, kurikulum dan karakteristik. Analisis kebutuhan berupa analisis silabus, dan materi yang akan digunakan. Analisis kurikulum dilakukan untuk menentukan Kompetensi Dasar, Indikator Pencapaian Kompetensi, tujuan pembelajaran. Analisis karakteristik siswa sebagai sasaran pengembangan lembar kerja siswa. Dari analisis tersebut akan diketahui kemampuan dan tingkatan berpikir siswa yang telah dicapai, sehingga disesuaikan dengan lembar kerja siswa yang akan dikembangkan.

\section{Tahap Design (Perancangan)}

Tahap ini meliputi pendesainan konsep produk baru (menuliskan SK dan KD, menetapkan indikator) menyusun bahan ajar, produksi prototype, self evaluation, dan prototype pertama. 


\section{Tahap Development (Pengembangan)}

Pada tahapan ini lanjutan dari penyusunan lembar kerja siswa yang telah dirancang dan didesain bagian prototype satu yang terdiri dari expert review yang bertujuan guna mengecek valid atau tidaknya suatu tahap tersebut. Pada tahap ini prototype produk pertama diujicobakan dalam ruang lingkup small group.

\section{Tahap Implementation}

Tahapan implementasi merupakan tahap pengujicobaan dalam kelompok kecil apakah ada perbaikan atau tidak. Di tahap ini jika ada perbaikan maka dilakukan revisi dan jika tidak ada maka langsung menghasilkan produk akhir.

\section{Tahap Evaluation}

Tahap ini merupakan tahap yang terakhir dalam penelitian ini. Tahapan ini untuk melihat apakah lembar kerja siswa yang sedang dikembangkan berhasil dan sesuai dengan harapan awal. Evaluasi pada tahap ini disebut dengan evaluasi formatif, karena digunakan untuk kebutuhan revisi. Kemudian setelah itu datadata tersebut dikelompokkan menjadi beberapa bagian yaitu: (1) Data pertama untuk evaluasi ini berupa data hasil uji ahli isi mata pelajaran; (2) Data kedua data evaluasi berupa hasil ujicoba individu; (3) Data ketiga data ujicoba kelompok kecil. Dimana pada penelitian pengembangan lembar kerja siswa ini hanya sampai pada tahap implementasi kelompok kecil untuk melihat valid dan praktis lembar kerja siswa berbasis masalah. Kriteria valid dan praktis yang diacu ditunjukkan pada tabel-tabel berikut:

Tabel 1. Kriteria nilai validitas

\begin{tabular}{cc}
\hline Nilai validitas $(\%)$ & Kriteria validitas \\
\hline $81-100$ & Sangat valid \\
$61-80$ & valid \\
$41-60$ & Cukup valid \\
$21-40$ & Kurang valid \\
$0-20$ & Tidak valid \\
\hline & Sumber $:$ Riduwan (2008:89)
\end{tabular}

Tabel 2. Kriteria kepraktisan

\begin{tabular}{cc}
\hline Angka & Keterangan \\
\hline $0 \%-20 \%$ & Sangat lemah \\
$21 \%-40 \%$ & Lemah \\
$41 \%-60 \%$ & Cukup \\
$61 \%-80 \%$ & Kuat \\
$81 \%-100 \%$ & Sangat kuat \\
\hline
\end{tabular}

Sumber : Riduwan dan Sunarto (2013) 


\section{HASIL DAN PEMBAHASAN}

Untuk menghasilkan produk lembar kerja siswa memerlukan beberapa tahapan dalam proses pengembangan. Menurut Nasution (2016) bahwa penelitian Research and Development (R\&D) bertujuan menghasilkan produk bahan ajar berupa modul matematika yang valid dan efektif dengan menggunakan pembelajaran berbasis masalah. Sejalan dengan pendapat di atas bahwa hasil penelitian yang telah dilakukan dalam pengembangan bahan ajar berupa LKS yaitu untuk menghasilkan produk yang berkualitas seperti kevalidan, kepraktisan dan keefektifannya. Namun penelitian ini dibatasi hanya melihat hasil valid dan praktisnya saja.

Proses serta hasil penelitian pada penelitian pengembangan ini diuraikan sebagai berikut:

\section{Tahap Analysis (Analisis)}

\section{a. Analisis Kebutuhan}

Analisis kebutuhan berupa menganalisis silabus, materi dan silabus yang dianalisis berdasarkan silabus yang dikeluarkan oleh Kemendikbud, sehingga dapat menentukan materi pembelajaran yang akan digunakan pada LKS yaitu Bentuk Aljabar.

\section{b. Analisis Kurikulum}

Analisis kurikulum dilakukan karena sebelum mengembangkan Lembar Kerja Siswa, harus tahu terlebih dahulu kurikulum apa yang sedang digunakan di SMPN 2 Sumber Marga Telang. Pada penelitian ini kurikulum yang digunakan adalah kurikulum 2013, dengan kompetensi dasar (KD) 3.5 menjelaskan bentuk aljabar dan melakukan operasi pada bentuk aljabar, 4.5 menyelesaikan masalah yang berkaitan dengan bentuk aljabar dan operasi pada bentuk aljabar. Indikator pencapaian kompetensi (1) mengidentifikasi unsur-unsur aljabar, (2) membuat bentuk aljabar dari masalah kontekstual, (3) menyelesaikan operasi bentuk aljabar, (4) menyelesaikan masalah nyata pada operasi bentuk aljabar. Tujuan pembelajaran (1) siswa mampu mengidentifikasi unsur-unsur aljabar, (2) siswa mampu membuat bentuk aljabar dari masalah kontekstual, (3) siswa mampu menyelesaikan operasi pada bentuk aljabar dan, (4) siswa mampu menyelesaikan masalah nyata pada operasi bentuk aljabar.

\section{Tahap Design (Perancangan)}

Tahap ini terdiri dari beberapa langkah perancangan seperti : 1) mengembangkan topik, 2) menyusun desain, Desain Lembar Kerja Siswa Berbasis Masalah dengan mengembangkan dan menetapkan kompetensi inti, kompetensi dasar, indikator dan materi. Pada tahapan desain lembar kerja siswa, dalam penelitian ini desain dirancang lebih difokuskan pada isi (Content), konstruk serta bahasa. Hasil desain ini diharapkan bisa memberikan perubahan dalam kegiatan sehingga tercapainya tujuan pembelajaran yang ingin dicapai. Setelah desain tersusun, dilakukan evaluasi diri (self evaluation) dengan menilai sendiri hasil desain produk Lembar Kerja Siswa sebelum diujicobakan untuk validasi oleh para ahli. 3) instrumen validasi LKS dilakukan bertujuan untuk 
mencapai tingkat kevalidan instrumen sebagai alat untuk pengambilan data sesuai dengan kompetensi yang telah dirumuskan.

\section{Tahapan Development (Pengembangan)}

Pada tahap pengembangan ini dilakukan validasi Expert Review. Produk Lembar Kerja Siswa (LKS) sebagai prototype pertama divalidasi oleh ahli untuk memperoleh komentar serta saran. Kemudian direvisi sesuai dengan saran yang diberikan.

Tabel 3. Rekapitulasi hasil penilaian ahliv

\begin{tabular}{ccc}
\hline Validator & Persentase & Keterangan \\
\hline Validator 1 & $90,76 \%$ & Sangat valid \\
Validator 2 & $82,25 \%$ & Sangat valid \\
Validator 3 & $84,55 \%$ & Sangat alid \\
\hline Rata-rata & $85,85 \%$ & Sangat valid \\
\hline
\end{tabular}

Berdasarkan pada tabel di atas dapat diketahui bahwa rata-rata penilaian dari 3 Ahli yaitu $85,85 \%$ terdapat pada interval $81 \%-100 \%$ yang berarti sangat valid. Dari rata-rata tersebut dapat disimpulkan bahwa lembar kerja yang dikembangkan valid.

Adapun saran dan hasil revisi dari Lembar Kerja Siswa yang diberikan oleh para ahli adalah sebagai berikut :

Tabel 4. Saran dari ahli dan hasil revisi
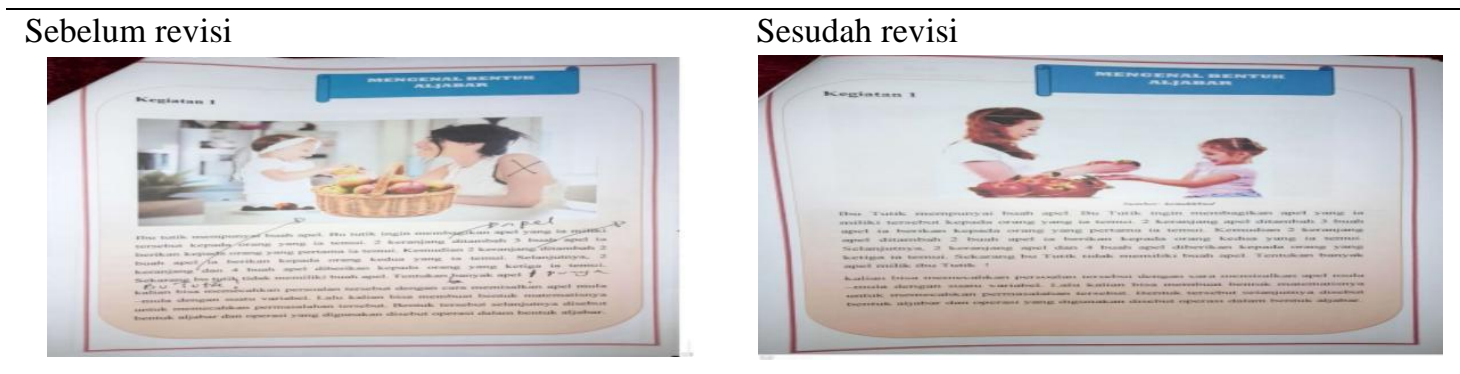

Komentar / saran:

perbaiki pengetikan, serta ganti gambar dengan yang lain
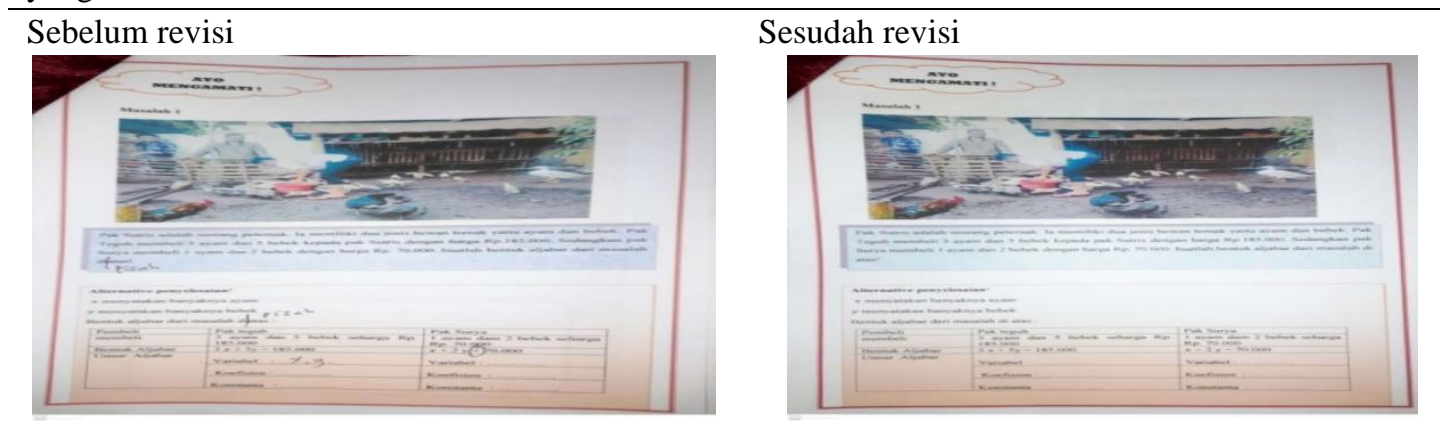

Komentar/saran: 
Perbaiki tanda penghubung antara variabel

\section{Sebelum revisi}

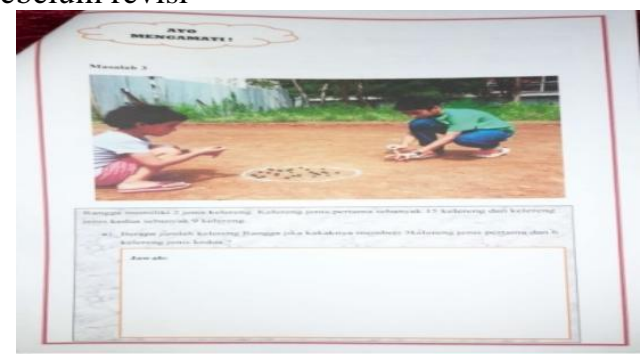

Komentar /Saran:

Tambahi lagi satu soal

\section{Sesudah revisi}

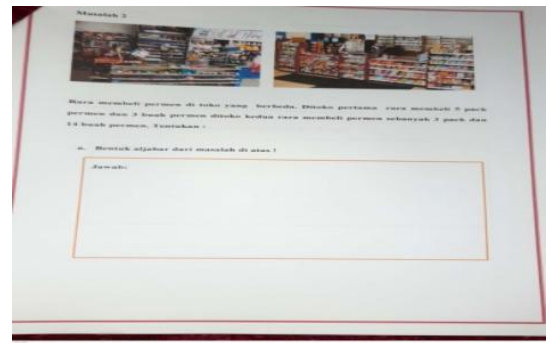

\section{Tahapan Implementation (Implementasi)}

Pada tahap ini LKS diujicobakan ke dalam kelompok kecil (Small Group) yang terdiri dari 6 orang siswa kelas VII SMPN 2 Sumber Marga Telang. Ujicoba dilakukan selama 2 kali pertemuan, yaitu pada tanggal 7 dan 8 desember 2020. Setelah dilakukan uji kepraktisan dengan lembar angket diperoleh nilai seperti pada tabel di bawah ini :

Tabel 5. Hasil angket respon siswa

\begin{tabular}{|c|c|c|c|c|c|c|c|c|c|c|}
\hline \multirow[b]{2}{*}{ No } & \multirow[b]{2}{*}{$\begin{array}{l}\text { Indikator } \\
\text { pertanyaan }\end{array}$} & \multicolumn{6}{|c|}{ Siswa } & \multirow[b]{2}{*}{$\begin{array}{l}\text { Skor yang } \\
\text { diperoleh }\end{array}$} & \multirow[b]{2}{*}{$\begin{array}{c}\text { Skor } \\
\text { maksi } \\
\text { mum }\end{array}$} & \multirow[b]{2}{*}{$\begin{array}{c}\text { Jumlah } \\
\%\end{array}$} \\
\hline & & $\mathrm{ASH}$ & M & AMA & STW & SR & YS & & & \\
\hline 1 & 1 & 4 & 4 & 5 & 5 & 3 & 3 & 24 & 30 & 80 \\
\hline 2 & 2 & 5 & 5 & 5 & 5 & 5 & 4 & 29 & 30 & 96,67 \\
\hline 3 & 3 & 5 & 5 & 4 & 5 & 5 & 4 & 28 & 30 & 93,33 \\
\hline 4 & 4 & 5 & 4 & 5 & 5 & 3 & 4 & 26 & 30 & 80 \\
\hline 5 & 5 & 5 & 4 & 5 & 3 & 3 & 4 & 24 & 30 & 80 \\
\hline 6 & 6 & 5 & 4 & 5 & 3 & 4 & 3 & 24 & 30 & 80 \\
\hline 7 & 7 & 1 & 2 & 3 & 2 & 3 & 1 & 12 & 30 & 40 \\
\hline 8 & 8 & 4 & 5 & 5 & 5 & 4 & 4 & 27 & 30 & 90 \\
\hline 9 & 9 & 4 & 5 & 5 & 4 & 3 & 4 & 25 & 30 & 83,3 \\
\hline 10 & 10 & 5 & 4 & 5 & 5 & 5 & 5 & 29 & 30 & 96,67 \\
\hline 11 & 11 & 5 & 4 & 5 & 4 & 5 & 5 & 28 & 30 & 93,33 \\
\hline 12 & 12 & 5 & 4 & 4 & 4 & 4 & 5 & 26 & 30 & 80 \\
\hline 13 & 13 & 2 & 1 & 3 & 2 & 1 & 1 & 10 & 30 & 33,33 \\
\hline 14 & 14 & 5 & 4 & 5 & 3 & 4 & 5 & 26 & 30 & 80 \\
\hline 15 & 15 & 4 & 1 & 3 & 2 & 1 & 1 & 12 & 30 & 40 \\
\hline \multicolumn{8}{|c|}{ Jumlah } & 350 & 450 & 77,78 \\
\hline
\end{tabular}

Data tabel di atas menyatakan perolehan persentase angket $77,78 \%$ yang terdapat pada interval 61\%-80\% dengan kategori kuat/praktis.

\section{Tahap Evaluasi}

Pada tahap ini dilakukan evaluasi terhadap komentar dan saran yang diberikan oleh para ahli (expert review) guna untuk kebutuhan revisi bahan ajar berupa lembar kerja siswa lalu diujicobakan pada kelompok kecil (small group). 
Evaluasi ini dilakukan pada lembar validasi para ahli (expert review) dan angket respon siswa yang diberikan pada saat tahap ujicoba kelompok kecil (small group) guna untuk mengetahui nilai valid dan praktis pada sebuah bahan ajar berupa lembar kerja siswa.

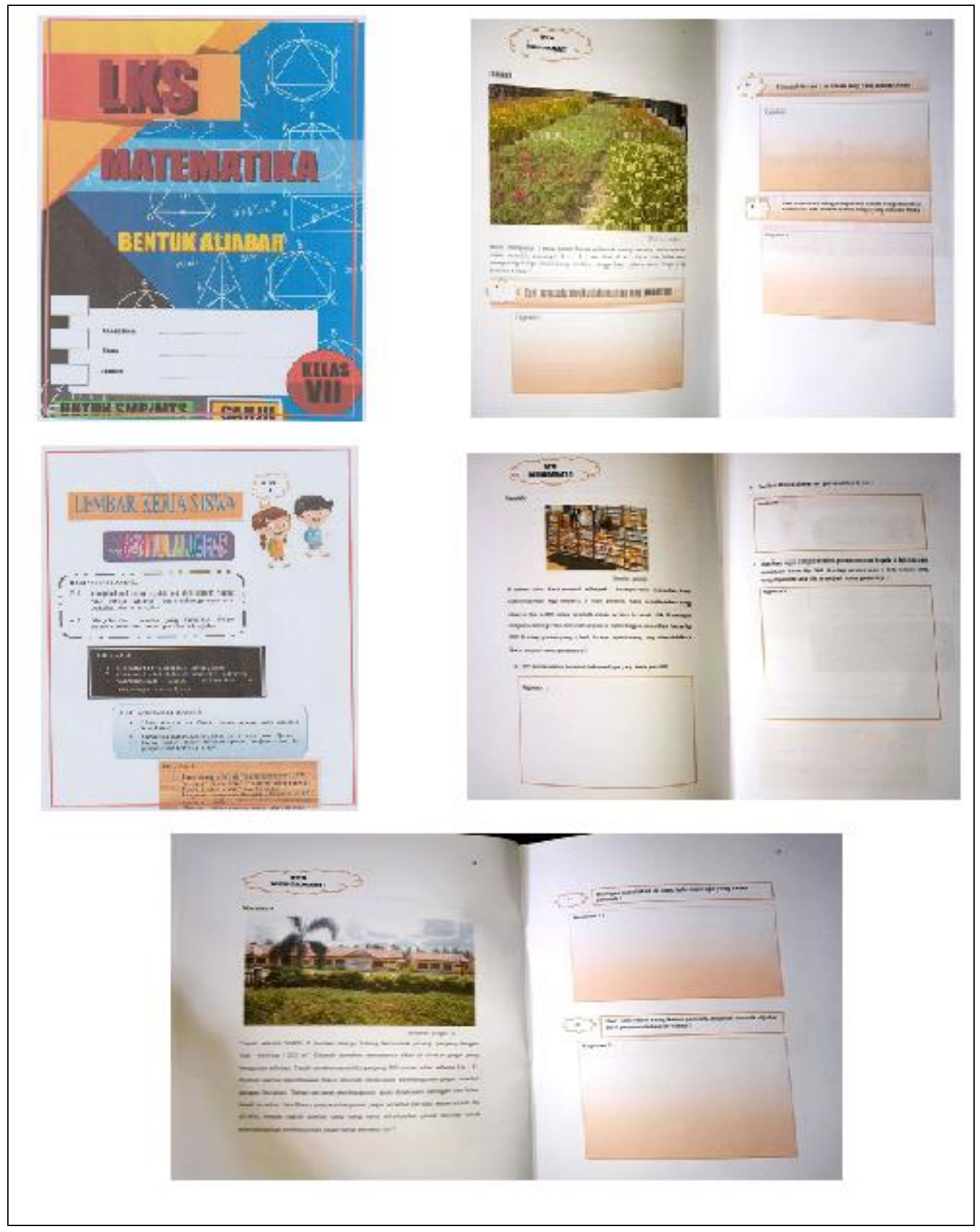

Gambar 1. Hasil Lembar Kerja Siswa yang dikembangkan 
Pengembangan LKS pada materi bentuk aljabar ini telah banyak juga dilakukan, diantaranya oleh Matutina (2014) dan Sari (2017), namun penyajian dan contohnya berbeda-beda. Matutina (2014) mengacu pada pendekatan kontekstual, Sari (2017) mengacu pada pembelajaran berbasis masalah, dan LKS pada penelitian ini menggunakan acuan yang sama dengan Sari (2017).

\section{SIMPULAN DAN SARAN}

Berdasarkan hasil penelitian yang dilakukan pada siswa kelas VII SMPN 2 Sumber Marga Telang maka diperoleh simpulan sebagai berikut : (1) LKS berbasis masalah pada materi Bentuk Aljabar di kelas VII SMP dinyatakan valid berdasarkan hasil validasi para ahli. (2) LKS berbasis masalah pada materi Bentuk Aljabar di kelas VII SMP ini dinyatakan praktis sesuai dengan hasil ujicoba produk dimana siswa dapat menggunakan lembar kerja siswa tersebut dengan baik.

Berdasarkan hasil penelitian serta simpulan maka ada beberapa saran yang dapat diberikan yaitu : (1) Agar guru dapat menggunakan bahan ajar berupa Lembar Kerja Siswa berbasis masalah khususnya pada materi Bentuk Aljabar yang telah dikembangkan ini. (2) Penelitian yang dilakukan ini hanya sampai pada tahap ujicoba kelompok kecil (small group) guna untuk melihat valid dan praktis, karena itu peneliti selanjutnya diharapkan agar dapat melanjutkan penelitian sampai pada tahap ujicoba lapangan supaya sampai pada tahap keefektifan suatu bahan ajar.

\section{DAFTAR PUSTAKA}

Hasibuan, I. 2015. Hasil Belajar Siswa Pada Materi Bentuk Aljabar di Kelas VII SMP Negeri 1 Banda Aceh Tahun Pelajaran 2013/2014. Jurnal Peluang, Vol. $4(1): 5-11$.

Ismail, F. 2014. Evaluasi Pendidikan. Palembang: Tunas Gemilang Press.

Kusumawati, E dan Irwanto, R.A. 2016. Penerapan Metode Pembelajaran Drill Untuk Meningkatkan Kemampuan Pemecahan Masalah Matematis Siswa Kelas VIII SMP. EDU-MAT Jurnal Pendidikan Matematika, Vol. 4(1) : 49-57.

Matutina, J.A. 2014. Pengembangan Lembar Kerja Siswa Mata Pelajaran Matematika Materi Bentuk Aljabar dengan Pendekatan Kontekstual Untuk Siswa SMP Kelas VII. Skripsi tidak diterbitkan. Yogyakarta: Universitas Negeri Yogyakarta.

Mulyatiningsih, E. 2012. Metode Penelitian Terapan Bidang Pendidikan. Bandung: Alfabeta.

Nasution, A. 2016. Pengembangan Modul Matematika Berbasis Masalah Untuk Meningkatkan Kemampuan Pemecahan Masalah Matematika Siswa. REKOGNISI : Jurnal Pendidikan dan Kependidikan, Vol. 1(1) : 47-63.

Prastowo, A. 2014. Pengembangan Bahan Ajar Tematik Tinjauan Teoretis dan Praktik. Yogyakarta: Kencana Prenadamedia Group.

Riduwan. 2008. Skala Pengukuran Variabel-variabel Penelitian. Bandung: Alfabeta.

Riduwan dan Sunarto. 2013. Pengantar Statiska untuk Penelitian Pendidikan, Sosial, Ekonomi, Komunikasi, dan Bisnis. Bandung: Alfabeta.

Sari, F.P. 2017. Pengembangan Lembar Kegiatan Siswa (LKS) Berbasis Masalah pada Materi Bentuk Aljabar untuk Siswa Kelas VII SMP Negeri 1 Sijunjung. Skripsi tidak diterbitkan. Padang: STKIP PGRI Sumatera Barat. 
Syaifullah, M., dan Izzah, N. 2019. Kajian Teoritis Pengembangan Bahan Ajar Bahasa Arab. Arabiyatuna Jurnal bahasa arab, Vol. 3(1) : 127-144.

Tanjung, H. S., dan Nababan, S. A. 2018. Pengembangan Perangkat Pembelajaran Matematika Berorientasi Model Pembelajaran Berbasis Masalah (PBM) Untuk Meningkatkan Kemampuan Berpikir Kritis Siswa SMA Se-Kuala Nagan Raya Aceh. Genta Mulia Jurnal Ilmiah Pendidikan, Vol. 9 (2) : 56-70.

Wardoyo, S. M. 2013. Pembelajaran Konstruktivisme : Teori dan Aplikasi Pembelajaran dalam Pembentukan Karakter. Bandung: Alfabeta.

Yueni, D. R. 2018. Diagnosis Kesulitan Belajar Matematika Materi Operasi Aljabar Pada Siswa SMP Kelas VII. Simki-Techsain, Vol. 2(6) : 1-7. 